\title{
Wellens Syndrome Presenting with Sudden Cardiac Arrest
}

\begin{abstract}
政
ABSTRACT

Wellens syndrome is characterised by changes in electrocardiogram precordial lead T-waves accompanied by proximal stenosis of the left anterior descending artery. Diagnostic criteria include T-wave changes plus a history of anginal chest pain without serum marker abnormalities, with significant ST-segment elevation and lack of Q waves. Wellens syndrome results in anterior wall acute myocardial infarction and cardiac death. We describe the case of a 33-year-old man who presented to the emergency clinic with cardiac arrest.

Keywords: Wellens syndrome, T-wave changes, cardiac arrest

\section{Introduction}

Wellens syndrome was first described in 1982 and is a syndrome characterized by critical stenosis of the left anterior descending (LAD) artery and unique electrocardiogram (ECG) findings. It was first demonstrated by the detection of critical LAD artery stenosis in a group of patients with angina pectoris (1). There are two different ECG patterns. Type A pattern is less visible and more specific, and characterized by the presence of biphasic T-waves, which are mostly seen in precordial derivations, especially in V2-V3. Type B pattern is more common and is characterized by deep and symmetrical T-waves in the anterior derivation $(1,2)$. In its etiology, there is a critical stenosis of LAD artery, and when undiagnosed, it may result in myocardial infarction or even death. Here, we present a young patient who was brought to the hospital with cardiac arrest and had Wellens syndrome pattern on ECG and 98\% stenosis in the LAD artery on coronary angiography and underwent restenosis treatment.
\end{abstract}

\section{öz}

Wellens sendromu prekordiyal T-dalga değișikliği ve sol ön inen arterin kritik darlığı ile karekterizedir. Tanı kriterleri T-dalgası değişiklikleri ve serum enzim yükselmesi olmaksızın anjinal göğüs ağrısı öyküsü, Q dalgası yokluğu, belirgin ST- segment elevasyonunu içerir. Wellens sendromu akut yaygın ön duvar enfarktüsü veya kardiyak ölüm ile sonuçlanabilmektedir. Burada acil kliniğe ani kardiyak arrestle getirilen 33 yaşında erkek hasta sunulacaktır.

Anahtar Kelimeler: Wellens sendromu, T-dalga değișikliği, kardiyak arrest

\section{Case Report}

A 33-year-old male patient was brought to our emergency clinic with a picture of respiratory and cardiac arrest. In his history, it was learned that there was a feeling of pressure in the chest for the last few months whose frequency and duration increased gradually in the last week, and that there were no additional suggestions after the ECG taken at the health institution he applied a week ago. It was stated by his relatives that he suddenly collapsed in the morning, could not breathe and became bruised and was brought to the emergency room quickly. It was learned that he had a history of smoking 20 packs/year, occasional alcohol and infrequent substance use. Cardiovascular resuscitation was performed in the patient, whose respiration was not observed and did not have a heart beat at admission. After the intervention, the patient who had a peak heartbeat but had insufficient spontaneous respiration was taken to the intensive care unit. The patient's ECG at admission also showed high widespread ST in V1-V6 derivations. In the ECG performed 1 week ago, aV2-V4 biphasic T-wave was observed (Figure 1). Emergency cardiac catheterization was performed with the diagnosis of Wellens syndrome and widespread anterior wall myocardial infarction. In coronary angiography, critical stenosis (98\%) was detected in the proximal LAD artery and it was revascularized (Figure 2, 3). He was extubated on the second day because he had spontaneous breathing. Antibiotherapy was started when pneumonic consolidation was observed in the chest radiography of the patient whose fever increased in the follow-up. On the seventh day, the patient, whose infective parameters regressed, had no additional problems, was discharged.
Address for Correspondence/Yazıșma Adresi: Hanife Usta Atmaca MD, University of Health Sciences Turkey, İstanbul Training and Research Hospital, Clinic of Internal Medicine, İstanbul, Turkey

Phone: +90 5303122973 E-mail: hanifeusta@yahoo.com ORCID ID: orcid.org/0000-0002-6591-4810

Cite this article as/Atıf: Yumrutepe S, Bozkurt Y, Usta Atmaca H, Pişkinpaşa ME. Wellens Syndrome Presenting with Sudden Cardiac Arrest. İstanbul Med J 2020; 21(Suppl 1): 6-8.
Received/Geliș Tarihi: 24.12.2019 Accepted/Kabul Tarihi: 03.03.2020

(C) Copyright 2020 by the University of Health Sciences Turkey, Istanbul Training and Research Hospital/istanbul Medical Journal published by Galenos Publishing House.

(C) Telif Hakkı 2020 Sağlık Bilimleri Üniversitesi Istanbul Ĕgitim ve Araștırma Hastanesi/Istanbul Tıp Dergisi, Galenos Yayınevi tarafından basılmıștır. 


\section{Discussion}

T-wave changes seen in the ECG in Wellens syndrome can often be overlooked in the symptom-free period or are generally considered as non-specific. When not recognized, myocardial infarction can even result in death. The patient who is diagnosed with with intermittent chest pain or ambiguous complaints, a T-wave change in the ECG performed at the moment when there is no complaint of pain is characterized. In patients with a type A pattern on the ECG, the findings may turn into a type B pattern over time. Chest pain can be specific and non-specific.

de Zwaan et al. (2) first identified Wellens syndrome in 180 out of 1,260 patients with angina in the presence of typical ECG changes and stenosis

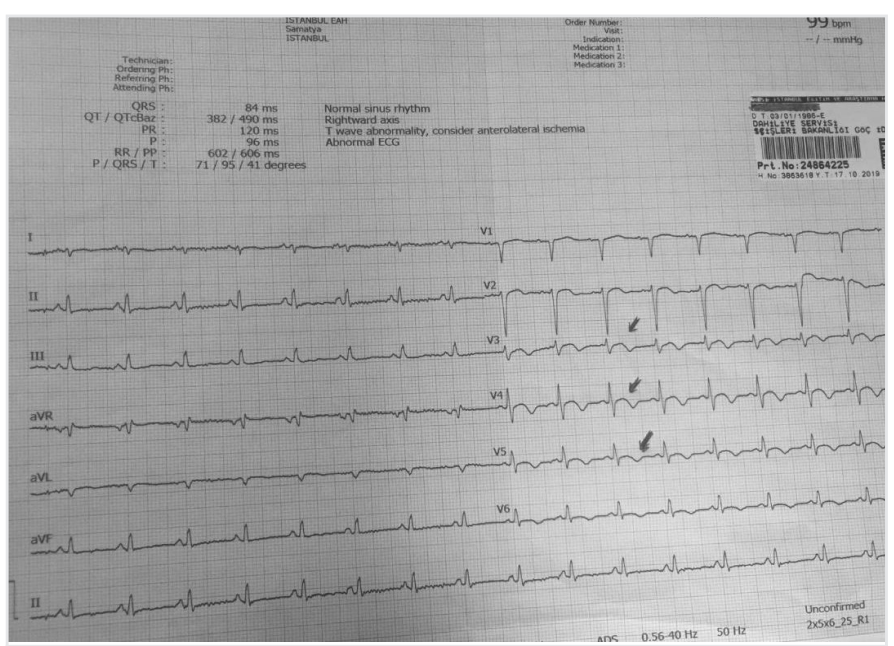

Figure 1. Negative T-waves in V3-5 derivations on electrocardiography at admission

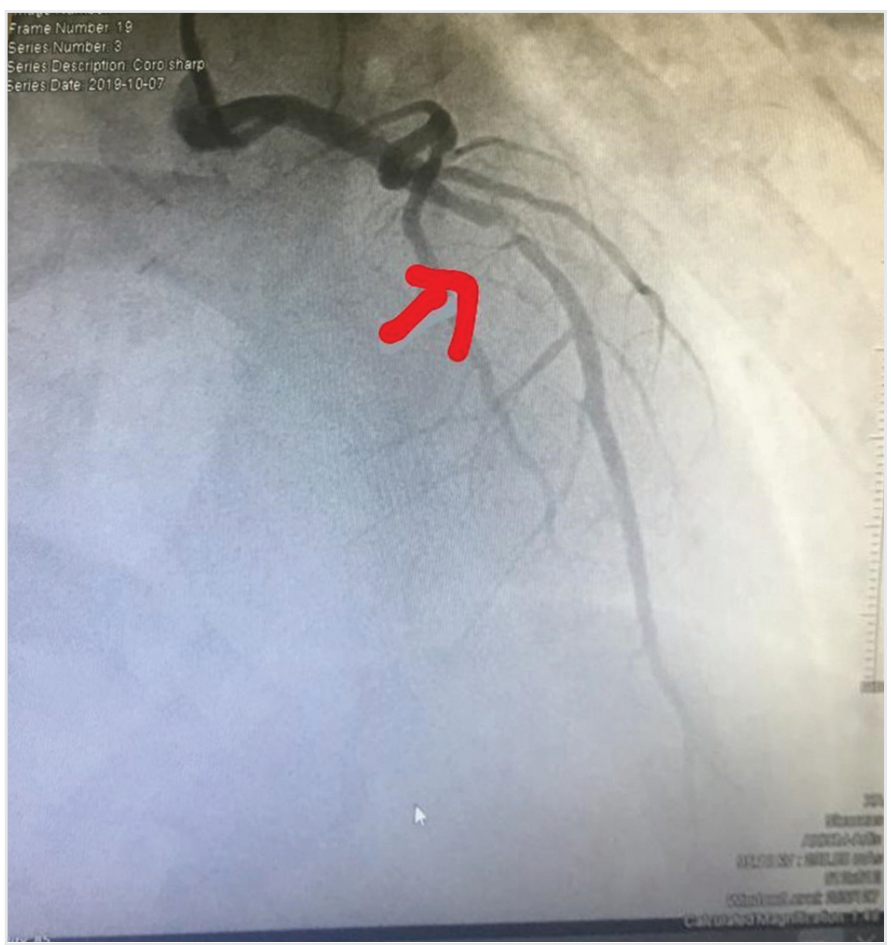

Figure 2. Coronary angiography showing $95 \%$ stenosis in the lumen of the proximal segment in the left anterior descending coronary artery

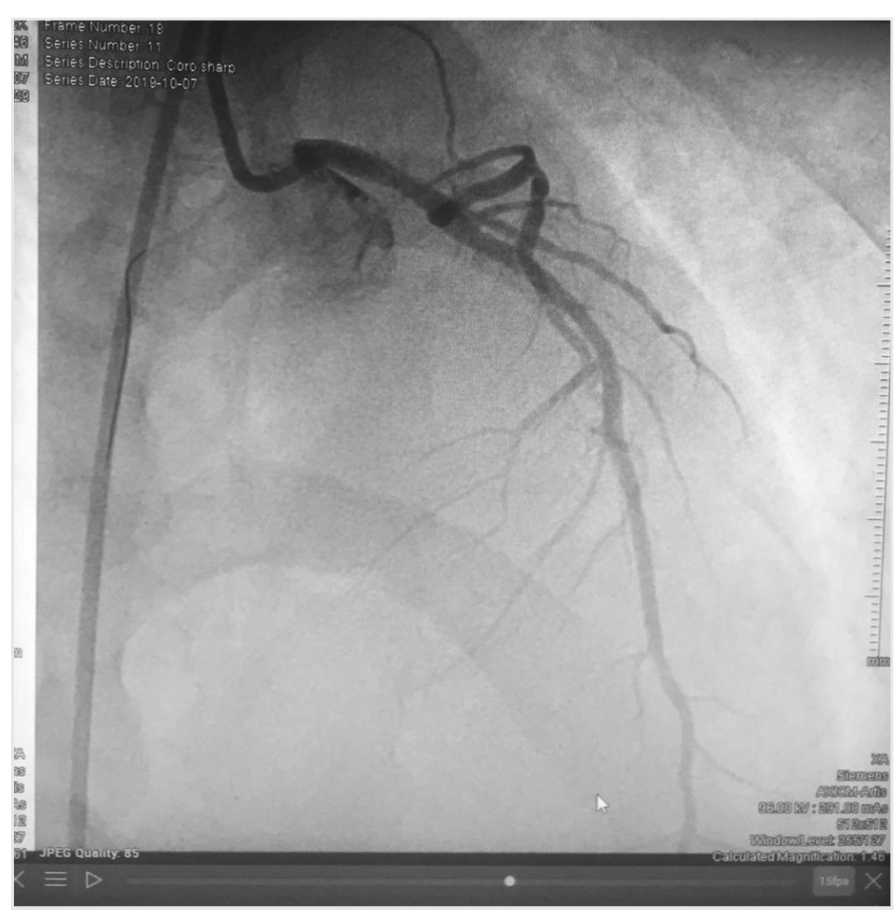

Figure 3. After successful revascularization, re-flow was enabled in left anterior descending

in the proximal LAD artery. While 108 patients had typical ECG findings at admission, it was detected later in 72 patients.

Diagnostic criteria of Wellens syndrome are intermittent chest pain, biphasic or symmetrical deep inverted T-waves primarily in V2 and V3, absence of pathological precordial Q waves, minimal increase or absence of cardiac enzymes (3). ECG findings in Wellens syndrome are typical before myocardial infarction develops, and recognition during this period is life-saving. When diagnosed, the first procedure to be performed is conventional angiography $(4,5)$.

In some cases, ECG findings are seen without LAD stenosis, this situation is called pseudo-wellens. These are acute cholecystitis, congenital myocardial band, Takotsubo cardiomyopathy and substance abuse. In such cases, a good history and clinical examination should be evaluated. As a matter of fact, in the study conducted by Kobayashi et al. (6), the analysis of 424 patients with non-ST elevation myocardial infarction revealed a Wellens ECG pattern in $4.2 \%$ of the patients, but LAD stenosis in only $50 \%$.

Although the cause of dynamic ECG changes is not fully known, LAD mimics vasospasm in the artery. It is thought that malnutrition and subsequent reperfusion may cause ECG changes.

This case resulted in sudden cardiovascular arrest due to the fact that the patient was not diagnosed despite the presence of non-specific chest pain prior to it. This reveals the importance of early diagnosis in Wellens syndrome. The incidence of myocardial infarction and sudden death has significantly increased in these patients, and revascularization is recommended when the diagnosis is made (3). 


\section{Ethics}

Informed Consent: Written informed consent was obtained from the patient for publication of this case report and any accompanying images.

Peer-review: Externally and internally peer-reviewed.

Authorship Contributions: Surgical and Medical Practices - S.Y., Y.B., H.U.A., M.E.P.; Concept - H.U.A., M.E.P.; Design - H.U.A.; Data Collection or Processing - S.Y.; Analysis or Interpretation - Y.B.; Literature Search S.Y., Y.B., M.E.P.; Writing - S.Y., Y.B., H.U.A., M.E.P.

Conflict of Interest: No conflict of interest was declared by the authors.

Financial Disclosure: The authors declared that this study received no financial support.

\section{References}

1. de Zwaan C, Bär FW, Wellens HJ. Characteristic electrocardiographic pattern indicating a critical stenosis high in left anterior descending coronary artery in patients admitted because of impending myocardial infarction. Am Heart | 1982; 103: 730-6.

2. de Zwaan C, Bär FW, Janssen JH, Cheriex EC, Dassen WR, Brugada P, et al. Angiographic and clinical characteristics of patients with unstable angina showing an ECG pattern indicating critical narrowing of the proximal LAD coronary artery. Am Heart J 1989; 117: 657-65.

3. Rhinehardt J, Brady WJ, Perron AD, Mattu A. Electrocardiographic manifestations of Wellens' syndrome. Am J Emerg Med 2002; 20: 638-43.

4. Drobni ZD, Károlyi M, Heltai K, Simon A, Merkely B, Maurovich-Horvát P. Wellens' syndrome depicted by coronary CT angiography. J Cardiovasc Emerg 2016; 2: 185-7.

5. Abulaiti A, Aini R, Xu H, Song Z. A special case of Wellens' syndrome. J Cardiovasc Dis Res 2013; 4: 51-4.

6. Kobayashi A, Misumida N, Kanei Y, Fox J. CRT-111 prevalence and prognostic value of Wellens' sign in patients with non-ST elevation myocardial infarction. JACC Cardiovasc Interv 2015; 8: 11-2. 